\title{
Estimation of the Middle Ural Transaction Sector
}

\author{
Evgeny V. Popov ${ }^{1,2,3}$, Anna Y. Veretennikova ${ }^{2,3, *}$ \\ ${ }^{1}$ Corresponding Member of the Russian Academy of Sciences \\ ${ }^{2}$ Institute of Economics of the Ural Branch of the Russian Academy of Sciences, Russian Federation \\ ${ }^{3}$ Institute of Public Administration and Entrepreneurship of the Ural Federal University, Russian Federation
}

Copyright (C) 2015 Horizon Research Publishing All rights reserved.

\begin{abstract}
In this study the authors reviewed the definition and the structure of the transaction sector as well as methods used for measuring its size. In the paper the authors presented the analysis, comparison, and systematisation of existing approaches to the estimation of the transaction sector and offer a method for measuring the transaction sector in the region. This method was based on the North's and Wallis's approach however adjusted to the peculiarities of statistical data in the area. The transaction sector was considered to include: (1) transaction activities and (2) activities aimed at the optimization of transaction costs of economic agents. The size of the pure transaction sector (financial activities) was taken as provided by the Federal State Statistics Service. To quantify the share of transaction activities in the mixed section the authors used the technique suggested by North and Wallis for the estimation of the transaction sector within firms. The share of transaction activities in the mixed section was taken as equivalent to the share of wages paid for transaction activities in the total wages paid in each section. The findings of this study clearly showed the growth of the share of the transaction sector in the Middle Urals (Russia) in 2005-2009 from $26.8 \%$ to $29.8 \%$. Analysing the reasons underlying these changes, the authors have attempted to determine the factors having affected the transaction sector dynamics.
\end{abstract}

Keywords Transaction Sector, Transformation Sector, Institutional Environment, Estimation, The Middle Urals

JEL: O14, O17, 043

\section{Introduction}

The role of transaction costs in economic development today is a key study area in the field of institutional economics. Neoclassical economics is known to ignore transaction costs and not be able to assess the real state of economic process. The opportunity of institutional economics to decide this problem and both describe and forecast economic changes increases the research interest in this area.
The notion of transaction costs underpins the concept of the transaction sector. R. Coase used the term of transaction costs trying to explain the existence of firms in his paper "The nature of the firm». His definition of transaction costs incurred in making an economic exchange, or the cost of discovering relevant prices [1].

In addition, the transaction sector gives the institutional environment in which the transformation sector develops thus linking production and markets. However, the role that the transaction sector plays in the economic development remains underestimated.

In an attempt to quantify transaction costs in the American economy, D. North and J. Wallis introduced the concept of the transaction sector [2]. They stated that economic activities and actors involved in economic exchange constitute the transaction sector. The method for measuring the transaction sector suggested by these authors established the foundation for the development and advancement of other research methods and techniques. These have been used to measure the transaction sector in Australia [3], the New Zealand France [4], France [5], Argentina [6], the Kingdom of the Netherlands [7], Poland [8], West Germany [9-11], Bulgaria [16], China [17], Russia [18-20], etc.

In this way the paper allocates three stages in evolution of transaction sector studies. The first stage is preliminary and dated from 1937 to 1986 . On this stage R. Coase coined the concept of transaction costs and, thus, and it caused the broad discussion in this issue. The second stage is dated from 1986 to 1997. In this time D. North and J. Wallis suggested the transaction sector concept to estimate transaction costs in the economy of the USA. But their approach is known to have been criticized by L. Davis in comments to their paper [2]. The third stage is dated from 1997 to present time. It is the stage of growing interest to this study field and some works presented in Figure 1.

Figure 1 presents the diversity of studies evaluating the transaction sector.

The very impressive results notwithstanding, these methods and techniques still very much depend on the quality of current statistical data. However in this paper we were able to identify three approaches to the transaction sector estimation. 


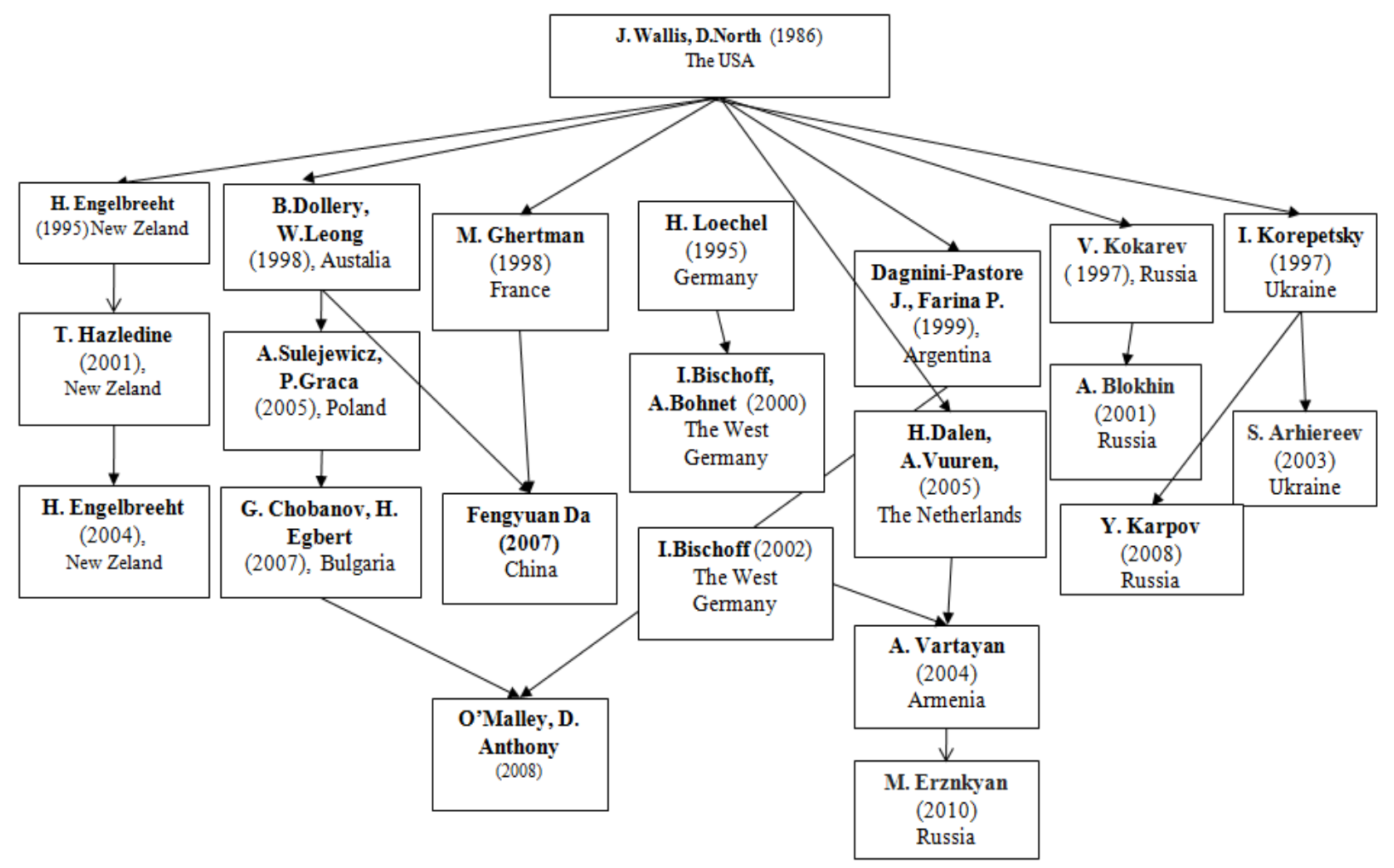

Figure 1. The evolution of transaction sector studies in the economic literature

The method suggested by North and Wallis differentiates all activities into (1) industries primarily producing non-transaction goods or services and (2) industries focused on the production of transaction services. In their view, resources used in finance, insurance, real estate, wholesale and retail trades can be classified as transaction industries. In order to estimate the transaction sector within firms, they identified jobs primarily concerned with transaction functions followed by the estimation of the wages of employees doing these jobs [2].

Modifying North and Wallis's approach Bischoff quantified the share of transaction activities within different industries in West Germany in 1985-1993[9]. By grouping these activities into transaction and transformation activities Bischoff calculated the share of transaction activities for all the industries studied. Unique to his work is the analysis of both the broad and narrow definitions of the transaction sector.

Dalen and Vuuren's technique is different compared to the traditional way of the estimation of the transaction market as the aggregate of the sector that provides many transaction tasks [7]. In order to estimate the transaction sector in the Dutch economy they calculated the number of people employed in transaction jobs. Dalen and Vuuren distinguished the following five 'transaction' tasks: pure trade, complementary activities, trading ideas and information, monitoring, transport and distribution. They estimated the transaction sector size and structure using three different measurements - the number of persons, the hours worked, and the wages. We would like to stress that this technique is rather laborious and requires very specific data.

Reviewing the available literature made us notice the following gaps in the papers published. First of all, there is no clear understanding of the role the transaction sector plays in the economic development. A possible cause is that both the concept of transaction sector itself and the entire filed of research are relatively young. Secondly, the transaction sector boundaries are still unclear due to the lack of methods to distinguish between the transaction and transformation activity types accurately. Thirdly, the methods described build on the available statistical data and thus are country-specific.

This paper advances and broadens the discussion on the importance of the transaction sector for economic growth. The aim of this paper is to analyze, compare and systematize approaches and methods used for the estimation of the transaction sector and to suggest a method for measuring the transaction sector in a region. Also the authors of this paper discuss some factors affecting the size of the transaction sector.

First we described our understanding of the nature of the transaction sector and the role that it played in the development of the economy. We then presented the data and a technique for the estimation of the transaction sector in the region. This is followed by a detailed presentation of the results. The paper concludes with a summary of our key findings and discussion. 
Table 1. Different approaches to measuring the transaction sector

\begin{tabular}{|c|c|c|c|}
\hline \multirow{2}{*}{$\begin{array}{l}\text { Research } \\
\text { dimensions }\end{array}$} & \multicolumn{3}{|c|}{ Authors } \\
\hline & D. North and J. Wallis [2] & I. Bischoff and A. Bohnet $[9,10]$ & H. Dalen and A. Vuuren [7] \\
\hline $\begin{array}{l}\text { ACTIVITIES AND } \\
\text { INDUSTRIES }\end{array}$ & $\begin{array}{l}\text { Finance, insurance, real estate, } \\
\text { wholesale and retail trade, transaction } \\
\text { jobs in nontransaction industries in } \\
\text { both private and public sectors. }\end{array}$ & $\begin{array}{l}\text { The narrow definition: trade, office } \\
\text { work, management (supervision), } \\
\text { security } \\
\text { The broad definition: trade; office } \\
\text { work, management (supervision); } \\
\text { security; planning and research; } \\
\text { education and informing }\end{array}$ & $\begin{array}{l}\text { 'Transaction' tasks such as } \\
\text { pure trade, complementary activities, } \\
\text { trading ideas and information, } \\
\text { monitoring and transport }\end{array}$ \\
\hline $\begin{array}{c}\text { THE UNIT OF } \\
\text { MEASUREMENT }\end{array}$ & Monetary (USD) & The share of transaction agents & $\begin{array}{l}\text { people, involved in transaction activities } \\
\text { hours, involved in transaction activities } \\
\text { wages of employee involved in } \\
\text { transaction activities }\end{array}$ \\
\hline $\begin{array}{l}\text { THE MEASURING } \\
\text { METHOD/ } \\
\text { TECHNIQUE }\end{array}$ & $\begin{array}{l}\text { The first step: to differentiate } \\
\text { industries into 1) industries that } \\
\text { produce primarily non-transaction } \\
\text { goods and services and 2) pure } \\
\text { transaction industries. } \\
\text { The second step: to measure the } \\
\text { transaction part of transformation } \\
\text { industries by dividing occupations into } \\
\text { transaction and transformation ones. }\end{array}$ & $\begin{array}{l}\text { Researchers measured the share of } \\
\text { transaction activities within } 50 \\
\text { industry separately. } \\
\text { They did not differentiate between } \\
\text { transaction industries and } \\
\text { non-transaction industries. }\end{array}$ & $\begin{array}{c}\text { Researchers integrate the number of } \\
\text { people performing tasks related } \\
\text { transactions }\end{array}$ \\
\hline $\begin{array}{l}\text { THE DATA } \\
\text { SOURCE }\end{array}$ & $\begin{array}{c}\text { Edwards (1943) [12]; Carson (1949) } \\
\text { [13]; Lebergott (1964) [14]; Kuznets's } \\
\text { (1961) [15]; NIPA GNP (National } \\
\text { Income and Product Accounts in Gross } \\
\text { National Product) }\end{array}$ & $\begin{array}{l}\text { Biennial survey by the German } \\
\text { StatistischesBundesamt }\end{array}$ & Structure of Earnings Survey \\
\hline
\end{tabular}

\section{Methods}

The paper overviews techniques which have been used by researchers to determinate the transaction sector size. In addition it analyses, compares, and systematizes these methods and suggests a method for measuring the transaction sector in the Middle Urals. Presented approaches showed that the estimation of the transaction sector size in an economy requires answers to the following questions:

- What activities and industries does the transaction sector include?

- What is the unit for measuring the transaction sector?

- What method/technique is used for measuring the transaction sector?

- Where does the data used for measuring the transaction sector comes from?

In Table 1 we presented the comparative analysis of different approaches to measuring the size of the transaction sector.

In our research we measured the transaction sector in the Middle Urals employing the method suggested by D. North and J. Wallis. For development technique for transaction sector estimation in the region we also had to respond to questions presented. We took the transaction sector to include: (1) transaction activities and (2) activities aimed at the optimization of economic agents' transaction costs. We used the statistical data on the Middle Urals provided by the Federal State Statistics Service. We grouped the economic activities in accordance to the Russian Classification of Types of Economic Activities (OKVED).

The first step in the suggested method was to single out activities forming the pure transaction sector. These included the only type, i.e. financial activities (Section $\mathrm{J}$ in OKVED). The second step was to fix those sections which include both transaction and transformation activities. We referred to this type of activities as mixed. These are listed in sections G, I, $\mathrm{K}$, L, and $\mathrm{O}$ (Table 2). The Table 2 shows what activities in these sections serve as transaction activities.

We perceive the transaction sector as the entity including both (1) the pure transaction sector and (2) transaction activities in mixed activities sections.

The size of the pure transaction sector (financial activities) is taken as provided by the Federal State Statistics Service.

To quantify the share of transaction activities in the mixed section the authors used the technique suggested by North and Wallis for the estimation of the transaction sector within firms. The share of transaction activities in the mixed section is taken as equivalent to the share of wages paid for transaction activities in the total wages paid in each section.

The third step was to calculate the total amount of resources involved in the transaction sector.

Here we must point out that this method does not take into account transaction costs occurring within firms. 
Table 2. Activities in OKVED involved in the transaction sector

\begin{tabular}{|c|c|c|}
\hline № & Section in OKVED & Activities involved in the transaction sector \\
\hline G & $\begin{array}{l}\text { Wholesale and retail trade; repair of motor } \\
\text { vehicles, motorcycles and personal and } \\
\text { household goods for personal use }\end{array}$ & $\begin{array}{c}50.1 \text { Sale of motor vehicles } \\
50.3 \text { Trade of motor vehicle parts and accessories } \\
50.4 \text { Trade of motorcycles, parts and accessories; maintenance and repair of motorcycles } \\
50.5 \text { Retail sale of automotive fuel } \\
\text { 51 Wholesale trade including trade through agents (except the trade of vehicles and } \\
\text { motorcycles) } \\
52.1 \text { Retail sale in non-specialized stores } \\
52.2 \text { Retail sale of food, beverages, and tobacco in specialized stores } \\
52.3 \text { Retail sale of pharmaceutical and medical goods, cosmetic and toilet articles } \\
52.4 \text { Other retail sale in specialized stores } \\
52.5 \text { Retail sale of second-hand goods in stores } \\
52.6 \text { Retail sale not in stores }\end{array}$ \\
\hline I & Transport and communications & $\begin{array}{c}\text { 63.3 Activities of travel agencies } \\
\text { 63.4 Organization of cargo transportation }\end{array}$ \\
\hline $\mathrm{J}$ & Financial activity & All activities \\
\hline $\mathrm{K}$ & Real estate, renting, and business activities & $\begin{array}{c}\text { 70 Real Estate } \\
\text { 72 Activities associated with using computers and information technologies } \\
72.1 \text { Consulting in computer hardware } \\
73 \text { Research and development } \\
\text { 74.1 Activities in law, accounting and auditing; consulting in administration } \\
74.20 .4 \text { Activities in standardization and metrology } \\
74.3 \text { Technical testing, certification and research } \\
74.40 \text { Advertising } \\
74.5 \text { Staff recruitment } \\
74.6 \text { Investigation and security } \\
74.81 \text { Photographic activities } \\
74.84 \text { Provision of secretarial, editorial services and translation services } \\
74.84 \text { Provion of other services }\end{array}$ \\
\hline $\mathrm{L}$ & $\begin{array}{l}\text { Public administration and defense; } \\
\text { compulsory social security }\end{array}$ & $\begin{array}{l}\text { 75.1 Public administration } \\
\text { 75.2Public services }\end{array}$ \\
\hline $\mathrm{O}$ & $\begin{array}{c}\text { Other community, social and personal } \\
\text { services }\end{array}$ & $\begin{array}{l}91 \text { Activities of public associations } \\
92.4 \text { News agency activities }\end{array}$ \\
\hline
\end{tabular}

Table 3. Sizes of the Middle Urals transformation and transaction sectors in 2005-2009, mln rubles

\begin{tabular}{|c|c|c|c|c|c|}
\hline & 2005 & 2006 & 2007 & 2008 & 2009 \\
\hline Transaction sector & 227,357 & 189,096 & 236,938 & 249,563 & 245,142 \\
\hline Transformation sector & 348,218 & 464,811 & 583,854 & 673,987 & 578,690 \\
\hline Total & 475,575 & 653,908 & 820,792 & 923,550 & 823,833 \\
\hline
\end{tabular}

\section{Results and Discussion}

\section{Changes in the transaction sector}

Tables 3 and 4 demonstrate the transaction sector dynamics in 2005-2009. The estimation is made and presented in Russian rubles (RUB) at prices current in 2005-2009. The average exchange rate for the period was 22 rubles for one dollar.

Tables 3 and 4 demonstrate that during the period in question the share of the transaction sector has grown by $3 \%$. Comparing these findings with findings in similar studies leads to the easy conclusion that this growth figure is pretty high. The rapid increase (from 26.8 to $28.9 \%$ ) of the share of the transaction sector in 2005-2006 is followed by a plateau at $28.9 \%$ in $2006-2007$. At the time of the global economic crisis - in 2008 - the size of the transaction sector dropped back to the 2005 level. In 2009 the share of the transaction sector in the GRP increased rapidly reaching the pre-crisis level (Figure 2).

Table 4. Shares of the Middle Urals transformation and transaction sectors in $2005-2009, \%$

\begin{tabular}{|c|c|c|c|c|c|}
\hline & 2005 & 2006 & 2007 & 2008 & 2009 \\
\hline $\begin{array}{c}\text { Transaction } \\
\text { sector, \% }\end{array}$ & 26.8 & 28.9 & 28.9 & 27.0 & 29.8 \\
\hline $\begin{array}{c}\text { Transformation } \\
\text { sector, \% }\end{array}$ & 73.2 & 71.1 & 71.1 & 73.0 & 70.2 \\
\hline Total & 100 & 100 & 100 & 100 & 100 \\
\hline
\end{tabular}




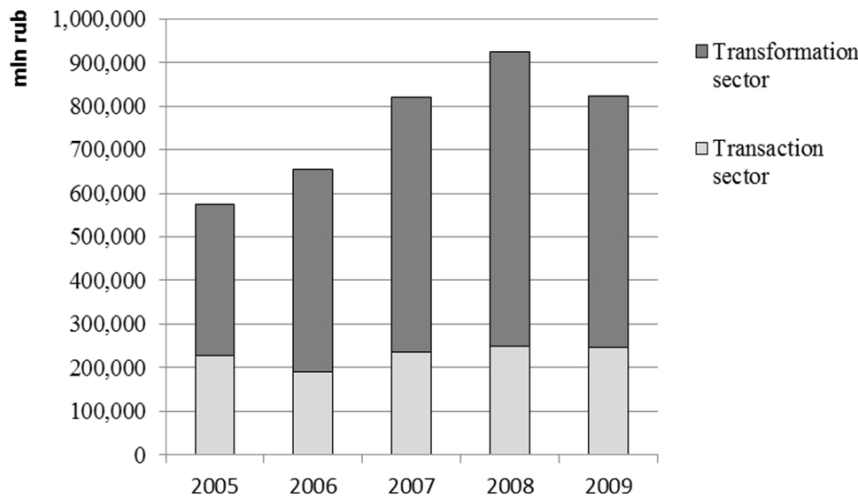

Figure 2. Dynamics of shares of the Middle Urals transaction and transformation sectors in 2005-2009

Additionally, Figure 3 clearly shows the real changes in the transaction sector. The size of the transaction sector remained stable in 2007-2009. We must point out that the cause for the difference between the relative and absolute figures is the growth of the transformation sector during the crisis.

Clearly the cause of changes in the share of the transaction sector lies in the rapid growth of the size of the transformation sector in 2007 and the decline in 2009. Most likely this is a result of the economic development in the Middle Urals exceeding the nationwide rates by $8-10 \%$. In 2009 the size of the transaction sector dropped by $2 \%$.

We must point out that the Middle Urals is positioned as an industrial area. In 2005-2009 the share of manufacturing industries in the GRP ranged from $27.7 \%$ to $33.5 \%$.

The share of manufacturing activities in the GRP ranged from $25 \%$ to $30 \%$. Moreover, the share of the transaction sector in the Middle Urals is much lower than figures cited in literature. This, however, can be attributed to the fact that the estimation method we employed does not take into account the transaction sector within firms. According to other studies this can vary from 4 to $14 \%$. Nevertheless, even if we introduce adjustments to correct this, the transformation sector would remain dominant.

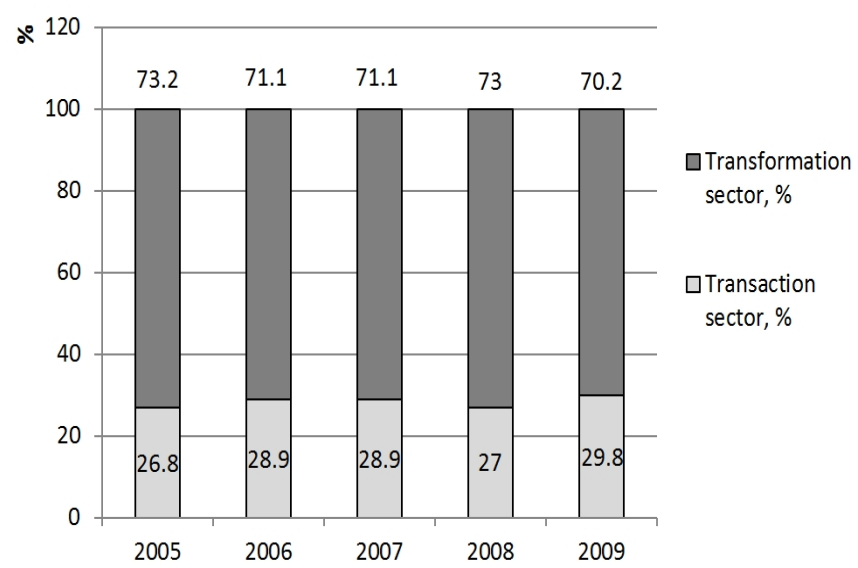

Figure 3. Indices of transaction and transformation sectors in the Middle Ural GRP

In the Figure 4 we presented the graphic comparison of the transaction sector dynamics in the Middle Urals and in Russia as a whole in 2005-2009.

The share of the transaction sector in the Middle Urals is more than one third higher that the same figure for Russia as a whole. The difference of such magnitude is most likely caused by the particular set of industries dominating the region.

The quantitative analysis of the transaction sector does not give any indication of whether the changes revealed should be considered negative or positive for the development of the economy.

The estimation of the transaction sector dynamics should take into account the relevant changes in institutional environment, legal regulations, and market trends.

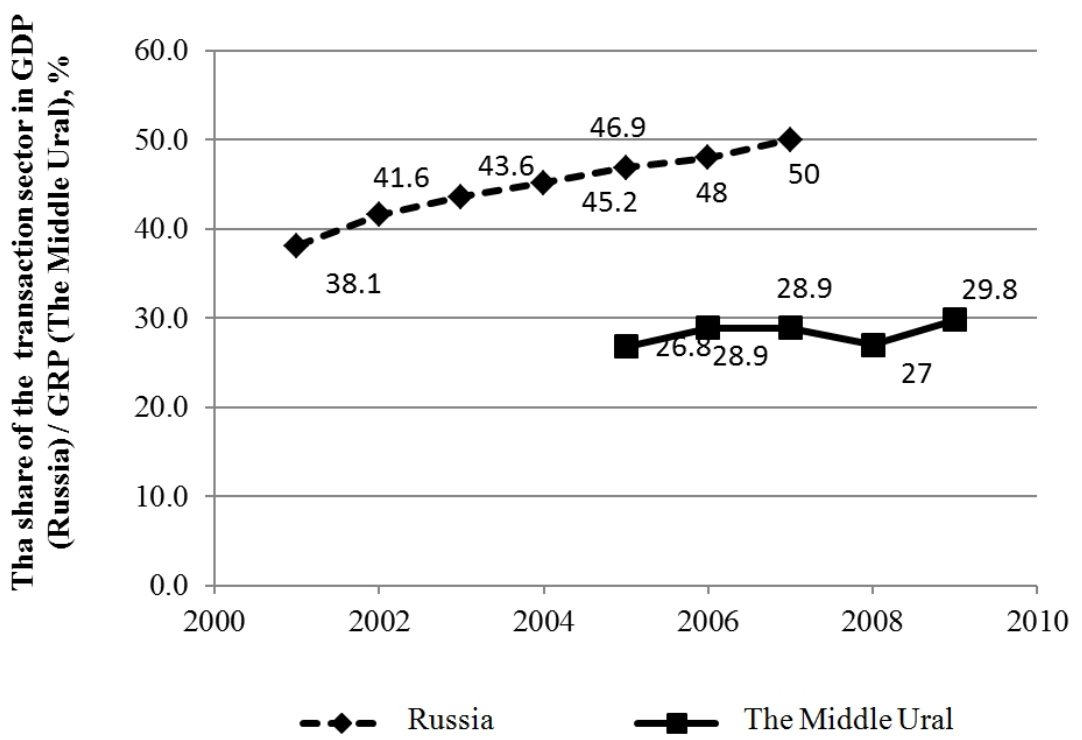

Figure 4. The dynamics of the transaction sector in Russia (Erznkyan,2012) and the Middle Urals 
Table 5. Structure of the Middle Urals transaction sector in 2005-2009

\begin{tabular}{|c|c|c|c|c|c|}
\hline Pure transaction / mixed activities & 2005 & 2006 & 2007 & 2008 & 2009 \\
\hline $\begin{array}{l}\text { Wholesale and retail trade; repair of motor vehicles, motorcycles } \\
\text { and personal and household goods for personal using }\end{array}$ & $74.7 \%$ & $73.9 \%$ & $73.3 \%$ & $68.1 \%$ & $65.2 \%$ \\
\hline Financial activity & $0.7 \%$ & $0.7 \%$ & $0.7 \%$ & $0.7 \%$ & $0.0 \%$ \\
\hline Real estate, renting and business activities & $13.8 \%$ & $13.1 \%$ & $12.3 \%$ & $14.3 \%$ & $16.4 \%$ \\
\hline Public administration and defense; compulsory social security & $8.9 \%$ & $11.2 \%$ & $12.2 \%$ & $15.2 \%$ & $17.2 \%$ \\
\hline Other community, social and personal services & $0.6 \%$ & $0.4 \%$ & $0.3 \%$ & $0.3 \%$ & $0.3 \%$ \\
\hline Total & $100.0 \%$ & $100.0 \%$ & $100.0 \%$ & $100.0 \%$ & $100.0 \%$ \\
\hline
\end{tabular}

The Table 5 shows a decline by almost $10 \%$ in wholesale and retail trade. However, the share of public administration increased. This could be interpreted as a result of the emphasis shift from private to public institutions.

\section{Factors affecting the size of the transaction sector}

Studying the dynamics of the transaction sector is underpinned by the analysis of factors affecting its size. We would like to include the following in this list.

The first factor is the development of transformation activities, i.e. the transformation sector, which causes the increase of the total amount of resources involved in the transaction sector thus stimulating its growth. While the transformation sector provides products and services to meet customer demand, the transaction sector creates and improves the conditions for the interaction between economic agents.

The second factor follows the first. The transaction sector magnitude depends on the number of transaction agents in the industry.

The third factor - the asset specificity - creates the competitive advantage for economic agents by increasing the transformation sector. However the purchase of the specific assets increases transaction costs and is accompanied by high risks of acquisition and using.

The institutional environment is the fourth factor. Institutions are able both to reduce and increase the transaction sector's size. Effective institutions reduce transaction costs. But lock-in effect or QWERTY-effect increases the transaction costs.

\section{Conclusions}

The transaction sector consists of economic activities and actors involved in economic exchange. We have presented the reader with a review of different approaches to the estimation of the transaction sector and the results of measuring the Middle Urals transaction sector (Russia). In our research we modified the method for measuring a region's transaction sector suggested by North and Wallis in the Middle Urals. We list the following four factors affecting change in transaction activities: the dynamics of the transformation sector, the institutional environment, the share of transaction agents in a market, and the asset specificity.

This research aims is to analyze, compare and systematize approaches and methods used for the estimation of the transaction sector and to suggest a method for measuring the transaction sector in a region. So we updated and broadened the discussion on the importance of the transaction sector for economic growth.

Further research is planned for measuring the transaction sector in the same region in 2010-2014. This will make it possible to track the dynamics of the development of the Middle Urals transaction sector enabling us to suggest various ways of using this data for the prediction of the development of the regional economy.

This field of study has some limitations due to the quality of the statistical data, the lack of clear boundaries of the transaction sector, the impossibility of a singular interpretation of a change in the transaction sector etc. It is clear, however, that the interest in this field of research continues to grow.

\section{Acknowledgements}

This study received support from the Russian Foundation for Basic Research from the grant number 14-06-00024 and the Russian Foundation for Humanities from the grant number 14-02-18004. The authors would also like to express their gratitude to the editor in chief and to the anonymous reviewers for the peer review.

\section{REFERENCES}

[1] Coase, R. The Nature of the Firm. Economica, New Series, 1937, Vol. 4, No. 16. pp. 386-405.

[2] Wallis, J. and North, D. Measuring the Transactional Sector in American Economy, 1870-1970, Long-term factors in American Economic Growth. Vol. 51 of The Income and Wealth Series, Engerman S. and R. Gallman (Ed). Chicago: University of Chicago Press, 1986. 
[3] Dollery, B. and Leong, W. Measuring the transaction sector in the Australian economy 1911 - 1991, Australian Economic History Review, 1998, №38 (3), pp. 207-231.

[4] Hazledine, T. Measuring the New Zealand transaction sector, 1956-98, with an Australian comparison, New Zealand Economic Papers, 2001, №35 (1). P. 77-100.

[5] Ghertman, M. Measuring Macro-economic Transaction Costs: A Comparative Perspective and Possible Policy Implications, Paper presented at the 2nd Annual Conference of the International Society for New Institutional Economics, 1998

[6] Dagnino-Pastore, J. and Farina, P. Transaction costs in Argentina, 3rd Annual Conference of the International Society for New Institutional Economics. Washington, USA, 1998, 16-18 September

[7] Dalen, H. and Vuuren, A. Greasing the Wheels of trade: A Profile of the Dutch Transaction Sector, De Economist, 2005 , №2, pp. 139-165.

[8] Sulejewicz, A. and Graca, P. Measuring the transaction sector in the Polish economy, 1996 to 2002, 9th Annual Conference of the International Society for New Institutional Economics, Barcelona, Spain, 2005, 22-25 September.

[9] Bischoff, I. Transaction activities, labor productivity and economic growth: empirical evidence from 50 West German Industries between 1985 and 1993, Jahrbuch für Wirtschaftswissenschaften, Review of Economics, 2002. URL:

http://www.jstor.org/discover/10.2307/20714986?uid=36284 3481 \&uid $=3738936$ \&uid $=16399008$ \&uid $=2129$ \&uid $=2$ \&ui $\mathrm{d}=70$ \&uid $=3$ \&uid $=362843231$ \&uid $=5911272$ \&uid $=67$ \&uid $=5911160$ \&uid $=62 \&$ uid $=60 \&$ sid $=21103187775793$

[10] Loechel, H. Institutionen, Transaktionskostenansatzes und wirtschaftliche Entwicklung : ein Beitrag zur neuen Institutionenökonomik und zur Theorie von Douglass C. North / von Horst Lochel. Berlin: Duncker und Humblot, 1995.

[11] Bischoff, I. and Bohnet, A. Gesamtwirtschaftliche Transaktionskosten und wirtschaftliches Wachstum, Journal of Economics and Statistics (Jahrbücher für Nationalökonomie und Statistik), 2000, Vol. 220, Issue 4. Pp. 419-437.
[12] Edwards, A.. Comparative occupation statistics for the United States, 1870 to 1940. In Sixteenth census of the United States, 1940. Washington: Government Printing Office.

[13] Carson, D. Changes in the industrial composition of manpower since the Civil War., 1944, Studies in income and wealth, 1943,Vol. 11., New York: NBER, Chandler, Alfred D. 1977.

[14] Lebergott, S. Labor force and employment, 1800-1960, Output, employment, and productivity in the United States after 1800, ed. Dorothy Brady, 1966, New York: Columbia University Press (for NBER).

[15] Kuznets S. Quantitative economic research: Trends and problems, 50th Anniversary Colloquium, New York: 1972, NBER, pp. 18-19.

[16] Chobanov, G. and Egbert, H. and Giuredzheklieva A. The Transaction Sector in the Bulgarian Economy, Paper Presented at the Conference of the International Society for New Institutional Economics, Reykjavik, 2007.

[17] Fengyuan, Da.Measuring Transaction Costs in the Chinese Economy (1978-2007), EALR, 2010, V. 1, № 2, Jul-Dez, pp. 281-300, URL:

http://portalrevistas.ucb.br/index.php/EALR/article/viewFile/ 1\%20EALR\%20281/1\%20EALR\%20283\%20-\%20pt

[18] Erznkyan, M. Transactional factors of industrial production. (A thesis in Economics), State University of Management, Moscow, 2010.

[19] Kokorev, B. Institutional transformation in modern Russia: analysis of the dynamics of transaction costs / / Problems of Economics, 1996, № 12, pp. 61-72.

[20] Blokhin, A. The institutional aspect of the analysis prices of Russian reforms, Studies on Russian Economic Development, 2001, № 1, Pp. 116-136.

[21] Popov, E. and Vlasov, M. and Veretennikova, A. Institutional Matrix of Knowledge Generation. In: Proceedings of the 12th European conference on knowledge management, 2011, Vol. 1, pp. 780-788.

[22] Popov E. Transaction Estimation of Institutions // Advances in Economics and Business. 2014. Vol.2. No 1. Pp. 58-64. 